Phil Booth

\title{
Images of Emperors and Emirs in Early Islamic Egypt
}

\section{Introduction}

At some point in the seventh century, an artist in Egypt sat down to decorate a Sahidic Coptic manuscript containing books of the Old Testament. ${ }^{1}$ At the conclusion to the Book of Job, on the blank half page beneath, and under the bold Coptic title 'Job the Just' (written in the same hand as the preceding text), this artist decided to depict the eponymous hero alongside his three daughters - Hemera, Kasia, and Amalthaias. The subsequent sketches, all frontal and standing in a row, are striking. On the left Job himself, tall and nimbate, appears with a short, circular beard, and with curled hair protruding beneath an ornate diadem topped with a cross; he wears a paludamentum fastened at his shoulder with a brooch, a knee-length belted tunic beneath a cuirass, and short boots; and he bears in his right hand a staff or sceptre, and in his left a globe. To the right, the three daughters all wear full-length tunics with ornate girdles, all have earrings, and the two older, central, women have their hair in a snood; the other wears a crown. ${ }^{2}$

It has long been recognised that the group is presented in Roman imperial dress, ${ }^{3}$ and indeed this is appropriate, given that the preceding Coptic text, based upon the Septuagint, includes a final chapter calling Job the king of Edom (Jb 42:17d). ${ }^{4}$ The dating of the manuscript on palaeographical grounds, and thus also of the drawing which seems original to it, has ranged from the fifth to ninth centuries, but the imperial inspiration for the figures is suggestive of a date before, or soon after, the Arab conquest (640-642), when access to imperial portraiture of various kinds was far easier. Indeed, it seems that the artist has based his depiction of Job on a particular emperor: Heraclius $(610-641) .^{5}$ Prior to his predecessor Phocas (602-610), emperors are depicted beardless, and Heraclius, on his coins up to 629,

1 Naples BN I.B.18. The manuscript passed into European collections in the eighteenth century, but seems to have been acquired from the White Monastery at Sohag; see the provenance described in $\mathrm{H}$. C. Evans and B. Ratliff, Byzantium and Islam: Age of Transition, 7th-9th Century (New York, NY, 2012) 15.

2 The image has featured in several prominent exhibitions, e.g., K. Weitzmann (ed.), Age of Spirituality: Late Antique and Early Christian Art, Third to Seventh Century (New York, NY, 1979) 36; Evans and Ratliff (cf. fn. 1) 15.

3 See D. V. Ainalov, The Hellenistic Origins of Byzantine Art, trans. E. Sobolevitch and S. Sobolevitch (New Brunswick, NJ, 1961 [first published, in Russian, in 1900-1901]) 66-68.

4 O. Kurz, 'An Alleged Portrait of Heraclius', Byz 16 (1942-3) 162-164.

5 See esp. I. Spatharakis, The Portrait in Byzantine Illuminated Manuscripts (Leiden, 1976) 14-20.

Ә OpenAccess. (c) 2021 Phil Booth, published by De Gruyter. (cc)BB-NC-ND This work is licensed under the Creative Commons Attribution-NonCommercial-NoDerivatives 4.0 International License. 
is the first to sport the same short beard reproduced in the portrait, where he is also depicted with similar hair and crown. ${ }^{6}$ In the same period to 629, moreover, an $a u$ gusta is far more prominent on several issues, in particular in bronze, than on those of his predecessors and successors. ${ }^{7}$ On this basis, we cannot posit a firm terminus ante quem for the manuscript and its image, since it is obvious that coins and other portraits of Heraclius would have circulated or survived even after the Arab conquest; but an approximate date range in the period 610-c. 700 seems sound.

We need not assume that the depiction of Job constitutes a 'portrait' of Heraclius (along with Martina, Epiphania the Elder, and Eudoxia), as is still sometimes suggested; ${ }^{8}$ nor should we assume that a Coptic text such as this must have been produced and circulated in anti-Chalcedonian circles. Nevertheless the Heraclian inspiration behind this remarkable portrait points to a religious reception of the emperor in Egypt which is more multi-faceted than is often supposed in modern literature. Such literature has often repeated, with little criticism, the account of Heraclius's reign contained within the normative narratives of the later Coptic Church, in which the emperor is memorialised, above all, as a religious persecutor. ${ }^{9}$ Although in recent scholarship our appreciation of the themes projected in and through these normative texts - themes of oppression, exile, and martyrdom - has grown far more sophisticated, this has still not translated into a thoroughgoing deconstruction of the basic historical narrative which frames, and reinforces, those same themes. ${ }^{10}$ In contrast, I will in this paper argue that the Heraclian persecution never happened in a meaningful sense; and, moreover, that the image of the persecuting emperor was developed in pursuit of three goals: to obfuscate the actual ambiguities created during the Roman restoration (629-642); to enable the later reintegration of fractured confessional communities; and to sanction a simultaneous transposition of the image of the good ruler from Christian to Muslim.

6 See, e.g., P. Grierson, Byzantine Coins (London, 1982) 90.

7 On the identification of the woman represented (Eudocia, Martina, or both) see the debate in C. Zuckerman, 'La petite Augusta et le Turc. Epiphania-Eudocia sur les monnaies d'Héraclius', $R N$ 150 (1995) 113-126; id. 'Au sujet de la petite Augusta sur les monnaies d'Héraclius', RN 152 (1997) $473-478$.

8 So Kurz, 'An Alleged Portrait' contra R. Delbrueck, Die Consulardiptychen und verwandte Denkmäler (Berlin and Leipzig, 1929) $270-274$.

9 See, e.g., the still influential account of C. D. G. Müller, 'Benjamin I Patriarch von Alexandrien', Mus 69 (1956) 313-340.

10 See, e.g., S. Davis, The Early Coptic Papacy: The Egyptian Church and Its Leadership in Late Antiquity (Cairo, 2005) 115-128; A. Papaconstantinou, 'Historiography, Hagiography, and the Making of the Coptic “Church of the Martyrs” in Early Islamic Egypt', DOP 60 (2006) 65-86. 


\section{Heraclius as Persecutor}

The image of Heraclius as persecutor is embedded in the historical memory of the Coptic Church. The Church's most important narrative source is the History of the Patriarchs of Alexandria $[H P]$ which, in its current form, compiles several separate collections of biographies of the patriarchs of Alexandria, stretching from the first to the thirteenth centuries. The first five collections were composed in Coptic, but were then translated into Arabic when, between 1088-1094, the Alexandrian deacon Mawhūb b. Manșūr b. Mufarriğ added two more biographies, in Arabic, to the existing collections; Mawhūb's continuators also wrote in Arabic. ${ }^{11}$ The individual collections, and most of their sources, now have no independent witnesses, but the final Arabic compilation exists in two principal recensions: the so-called 'Primitive,' which is more ancient, and the more diffuse and more famous 'Vulgate.' 12

The compilation covering the reign of Heraclius stretches from the patriarchate of Cyril (412-444) to that of Alexander (705-730), and was compiled in c. 715 by George the Archdeacon, a disciple of the patriarch John III (681-689) and notarios to Simon (c. 692-701). ${ }^{13}$ In its Life of Benjamin, the patriarch from 626 to 665, the HP describes how, following the end of the Persian occupation (619-629) - when the Chalcedonian throne of Alexandria had laid vacant - Heraclius appointed one Cyrus 'to be patriarch and governor (batrik wa-wālì) at the same time. ${ }^{14}$ At this, it continues, an angel warned the Severan patriarch Benjamin of his imminent persecution, and thus he fled from Alexandria, via Scetis, to the Thebaid. Then 'Heraclius and the Colchian' - al-muqawqas, a name derived from the Greek-Coptic soubriquet

11 For this see J. den Heijer, Mawhūb b. Manșūr b. Mufarriğ et l'historiographie copto-arabe: étude sur la composition de l'Histoire des patriarches d'Alexandrie (Louvain, 1989) 81-156.

12 For the 'Primitive' see C. F. Seybold, Severus b. al Muqaffa', Alexandrinische Patriarchengeschichte von S. Marcus bis Michael I (61-767) nach der ältesten 1266 geschriebenen Hamburger Handschrift (Hamburg, 1912). For the 'Vulgate' see B. Evetts, 'History of the Patriarchs of the Coptic Church of Alexandria', PO 1 (1904) 99-214, 381-518; 5 (1910) 1-215; 10 (1915) 357-552. On the limits of this distinction see P. Pilette, 'L'Histoire des Patriarches d'Alexandrie. Une nouvelle évaluation de la configuration du texte en recensions', Mus 126 (2013) 419-450.

13 Pace den Heijer (cf. fn. 11) 142-143, but his thesis (contra D. W. Johnson, Coptic Sources of the Arabic History of the Patriarchs of Alexandria, unpublished $\mathrm{PhD}$ thesis, Catholic University of America, 1974, 114) that George did not write the first part of the HP's Life of Alexander seems to be discounted in that Life's acknowledgement - at HP (Primitive) (Seybold 137); HP (Vulgate) (Evetts PO 5, 57) - of Anastasius II (713-715) as the current Roman emperor, which supports the suggestion in the editorial note of John, George's successor as compiler of patriarchal Lives, that George wrote up to the reign of Sulaymān b. 'Abd al-Malik (715-717); see HP (Primitive) (Seybold 151); HP (Vulgate) (Evetts PO 5, 91). Note that for the dates of the patriarchs I follow A. Jülicher, 'Die Liste der alexandrinischen Patriarchen im 6. und 7. Jahrhundert', in Festgabe von Fachgenossen und Freunden Karl Müller zum siebzigsten Geburtstag dargebracht (Tübingen, 1922) 7-23.

14 HP (Primitive) (Seybold 98); HP (Vulgate) (Evetts PO 1, 490). 
of the patriarch, who came from Lazica ${ }^{15}$ - ruled the land, and launched a great persecution of the orthodox. Heraclius, according to the $H P$, even seized Menas, the brother of Benjamin. The emperor's inquisitors then burnt Menas' flesh, knocked out his teeth, and then, when he would not confess the Council of Chalcedon, drowned him in a sack tossed into the sea. Heraclius 'was like the ravishing wolf consuming the (rational) flock' - and his target was 'the Theodosians' (i.e., the Severans). ${ }^{16}$

This image of Heraclius and his Alexandrian patriarch Cyrus is embedded in a range of Coptic literature. Our second Egyptian narrative source for the period is the Chronicle of John of Nikiu, a Severan bishop who is otherwise attested in the period c. 690-c. $700{ }^{17}$ The Chronicle - which stretches from creation to the Arab conquest - does not survive except in an Ethiopic version of a lost Arabic paraphrase of the Coptic original, and a lamentable lacuna has expunged three crucial decades. Chapter 110 thus concludes with the accession of Heraclius (610); while chapter 111 begins with the Arabs at war within Egypt (c. 640). For his famous account of the conquests, contained in chapters 111-121 of the Chronicle, John has made use of two main sources. The first is a narrative of Egyptian affairs, involving a consistent cast of characters, and focused first on events in the field, and then on affairs in Alexandria, in the period c. 640 - c. 642. It is almost certain that this source once embraced at least the late 630s, but that the aforementioned lacuna, deliberate or not, has decapitated it. The second source is a narrative of Constantinopolitan affairs in 641 which, as I have argued elsewhere, John himself has integrated within an earlier version of the text. ${ }^{18}$ John does not seem to have altered these sources to a significant extent, but has instead restricted himself to some small addenda, some of which are anti-Chalcedonian glosses on events.

Three times these glosses concern the patriarch Cyrus - even though, as we shall see, this creates a distinct discordance with John's wider source material. At one point in the narrative of the conquest, we read that the Arabs were emboldened upon witnessing the opposition of the people of the Thebaid towards the emperor Heraclius, 'because of the persecution which he visited upon all the land of Egypt on account of the orthodox faith, at the instigation of the Chalcedonian patriarch Cyrus.... ${ }^{19}$ In another place - following an anecdote which reports how some Gaian-

15 See the famous discussion of A. J. Butler, The Arab Conquest of Egypt and the Last Thirty Years of Roman Dominion (Oxford, 1902) 508-526.

16 HP (Primitive) (Seybold 99); HP (Vulgate) (Evetts PO 1, 491-492).

17 Ed. H. Zotenberg, Chronique de Jean, évêque de Nikiou (Paris, 1883). For John see HP (Primitive) (Seybold 120, 125); HP (Vulgate) (Evetts PO 5, 20 -22, 32-34); Mena of Nikiou, Life of the Patriarch Isaac ed. E. Porcher, 'Vie d'Isaac, patriarche d'Alexandrie de 686 à 689, écrite par Mena, évêque de Pchati', PO 11 (1915) 299-390, at 354.

18 P. Booth, 'The Last Years of Cyrus, Patriarch of Alexandria (†642)', in J.-L. Fournet and A. Papaconstantinou (eds), Mélanges Jean Gascou, TM 19 (Paris, 2016) 509-558.

19 John of Nikiu, Chronicle 115 (Zotenberg 203). 
ites (that is, anti-Severan Julianists) were punished after their failed attempt to avenge Cyrus's seizure of their properties 'in the time of persecution' - John emphasises how Cyrus, following the death of Heraclius and his own return from exile (c. 640-September 641), 'did not abandon his anger and persecution against the people of God, but began to heap evil upon evil. ${ }^{20}$ Then, at the conclusion to the text, when Roman forces have withdrawn and when the patriarch Benjamin has returned to Alexandria from exile (c. 644), John states: 'And all the people began to say, "This expulsion and the conquest of the Muslims were on account of the oppression of the emperor Heraclius and his tormenting of the orthodox at the hand of the patriarch Cyrus. For this reason the Romans were destroyed and the Muslims gained dominion over Egypt." 21 Thus, while the Chronicle for the most part omits the period in which Heraclius's persecution is said to have occurred, that persecution nevertheless assumes a prominent position within its narrative.

Heraclius's persecution also became embedded in the hagiographic imagination of the Coptic Church. Isaac the Priest's Life of Samuel Kalamon - which is extant in Arabic and Ethiopic versions, as well as in the Coptic original ${ }^{22}$ - is set around the 630s, but in its current form, at least, is the product of a period at least four generations after that of its hero. ${ }^{23}$ Echoing the narrative of the $H P$, it records how 'Cyrus the criminal' came to Alexandria in pursuit of Benjamin, and how the latter hid himself 'in the south of Egypt.' Cyrus, 'the Colchian (pchaukianos),' then sat upon the throne of Alexandria and, wielding 'civil authority (tarchē nnendumōsion)' issued the Tome of Leo, and dispatched 'a cruel magistrianus' to Scetis to enforce it. Samuel, of course, instead anathematised it, and was then subjected to a gruesome torture before being expelled along with his disciples. He retreated to the Fayyum, but soon Cyrus came south, 'persecuting in every place,' seeking after Benjamin, and forcing each monk whom he encountered both to recognise the Tome and to receive communion from his hand. When he reached the Fayyum, we read, the bishop Victor 'came out to meet him with great joy and the vainglory of the world,' and Cyrus then 'published from the city of Fayyum the defiled Tome of Chalcedon by the order of Justinian [sic] the false king of the Romans, who ordered that the entire province of Egypt commune with the defiled Tome of Chalcedon.' Thus, the text continues, Cyrus realised that if he could convert the monasteries, so too would follow the

20 John of Nikiu, Chronicle 115 (Zotenberg 206). On the strange placement of this episode see Booth (cf. fn. 18) 536.

21 John of Nikiu, Chronicle 221 (Zotenberg 220).

22 Sahidic: ed. A. Alcock, Isaac the Presbyter: The Life of Samuel of Kalamon (Warminster, 1983) (with 67-73 for fragments of a longer recension, and W. E. Crum, Catalogue of the Coptic Manuscripts in the British Museum [London, 1905] 381-382 for an unedited Bohairic version); Arabic: A. Alcock, 'The Life of Anbā Samaw'īl of Qalamūn', Mus 109 (1996) 321-345 and 111 (1998) 377-404; Ethiopic: F. M.E. Pereira, Vida do Abba Samuel do mosterio do Kalamon (Geneva, 1894). For the relations of the various versions: U. Zanetti, 'Notes sur la Vie de S. Samuel de Kalamon. Versions arabe at éthiopienne - Deux citations de la "prière de la fraction”, $A B 115$ (1997) 147-158.

23 Isaac the Priest, Life of Samuel 1. 
rest of the population. Thus '[h]e went out to all the monasteries, and the monks he found he forced to subscribe to the Tome of Chalcedon, and they took communion from his hand. ${ }^{24}$ Heraclius's persecution, then, according to Coptic tradition, was not limited to Alexandria, but extended across the region's monasteries.

\section{The Union under Cyrus}

The notion of an all-pervasive persecution in the later reign of Heraclius, as cultivated in the texts we have explored thus far, conceals a more complex situation at which the same texts sometimes hint. Following the Persian retreat from the Roman Near East, Heraclius and the Constantinopolitan patriarch Sergius had launched a series of diplomatic missions to restore union with those anti-Chalcedonian churches liberated from the Persians, based in part upon the doctrine of monenergism (Christ's single operation). This initiative met with some spectacular success, and for a fleeting moment brought anti-Chalcedonian Christians throughout Persia, Armenia, and the Levant into communion with Constantinople. ${ }^{25}$ The ambition of the initiative has not often been appreciated. For, following decades in which two rival church hierarchies had existed throughout the Roman East, it aimed to re-establish a single church in which all Christians were reunited.

Perhaps the most spectacular of these Heraclian unions was realised in Alexandria in the summer of 633, under the auspices of Cyrus. Embedded in the Acts of the Sixth Ecumenical Council is a Greek document bearing the title, 'Copy of the assurance (plerophoria) agreed between Cyrus, who was pope of Alexandria, and the party of the Theodosians.' This document records a union realised in the month of Pauni of the sixth indiction (June 633), and the nine articles of faith under which it occurred. Much contained within these articles is standard theological fare - the condemnation of Arius, Apollinarius, Nestorius, etc. - but the sixth and seventh articles are nevertheless remarkable. The former asserts that Christ is "from two natures, that is, from both Godhead and humanity, one Christ, one Son, "one enfleshed nature of God the Word" according to the sainted Cyril, without confusion, without change, without alteration, that is, one composite hypostasis (mia synthetos hypostasis)....' The Christological language is here striking, for the central Chalcedonian assertion of 'in two natures' is absent. The statement 'in two natures' does occur in the next, seventh, article, but with the qualifications characteristic of Cyril of Alexandria and his Severan interpreters. This anathematises whoever - while acknowledging that Christ is 'contemplated in two natures' - nevertheless does not recognise, first, that the divine Son is a single subject "“perfect in Godhead and perfect in hu-

24 Isaac the Priest, Life of Samuel 7-9 (Alcock 7-9).

25 For a full account see P. Booth, Crisis of Empire: Doctrine and dissent at the end of late antiquity (Berkeley CA, 2014) 200-208. 
manity," and in that respect and in that alone contemplated "in two natures, the same one suffering and not suffering according to one or the other," as the same sainted Cyril said, suffering humanly in the flesh as a man, but remaining impassible as God in the sufferings of his own flesh ...'; and, second, does not confess that, 'one and the same Christ and Son performed things befitting God and things human "with one theandric activity," according to the sainted Dionysius, distinguishing by contemplation alone the things from which the union came about, and mentally considering these things as remaining without change and without confusion after their natural and hypostatic union.... ${ }^{26}$ The anathema, therefore, responds to Severan concerns that the Chalcedonian creed (and, in particular, the Tome of Leo) saw in the natures two subsistent subjects, and countered this with the assertion that both human and divine things were performed with the single, divine-human operation of the Word incarnate.

Subsequent doctrinal discussions would focus upon this final assertion, of one operation in Christ (i.e., monenergism). This doctrine, let us note, was not pure Severanism, for it had also been embraced within certain neo-Chalcedonian circles of the later sixth and early seventh centuries. ${ }^{27}$ Nevertheless, what strikes the reader of the Plerophoria is the extent to which it responds to Severan criticisms of Chalcedon, adopts their qualifications to 'in two natures,' and suppresses explicit reference to the council itself. ${ }^{28}$ We must of course be sensitive to the fact that the document has no independent witness, and is embedded in the acts of a council convened to condemn monenergism's proponents. But as it stands, at least, the Plerophoria suggests a considerable effort on the part of the unionists to realise common ground, and to distance Chalcedon from the perceived Nestorianising tendencies of the Tome of Leo - quite different, then, from the narrative set out in the Coptic sources described above.

One more detail from the Plerophoria is perhaps salient. From other documents contained in the Acts of the Sixth Council, we know that Heraclius first encountered Cyrus, then bishop of Phasis, during doctrinal discussions on his earlier campaigns in Transcaucasia, and at an unknown point c. 630 he must have transferred him to the see of Alexandria. ${ }^{29}$ The text however refers to Cyrus as 'bishop by the grace of God, locum tenens of the apostolic throne of this Christ-loving city of the Alexandri-

26 CCP (681) act., ed. R. Riedinger, Concilium Universale Constantinopolitanum tertium, ACO Ser.2.2 (2 vols, Berlin, 1990-2) vol. 2, 598.

27 See K.-H. Uthemann, 'Der Neuchalkedonismus als Vorbereitung des Monotheletismus: Ein Beitrag zum eigentlichen Anliegen des Neuchalkendonismus', StP 29 (1997) 373-413; C. Lange, Mia Energeia: Untersuchungen zur Einigungspolitik des Kaisers Heraclius und des Patriarchen Sergius von Constantinopel (Tübingen, 2012).

28 See also H. Ohme, 'Oikonomia im monenergetisch-monotheletischen Streit', Zeitschrift für antikes Christentum 12 (2008) 308-334, at 314-315, 332-333.

29 See CCP (681) act. (Riedinger vol. 2, 534-536, 588-592). 
ans according to the divine degree of our good and serene masters. ${ }^{30}$ This means, therefore, that at the time of the union Cyrus was not patriarch but topoterètès, ${ }^{31}$ and that the emperor conferred the patriarchal title soon after, no doubt as a consequence of his success in effecting the union. ${ }^{32}$

That success is even acknowledged in the $H P$, though it is attributed, of course, to the evil machinations of Cyrus. As a result of his persecution, the text claims, a 'countless number' of the orthodox erred - some through persecution, some through bribes and honours, and some through persuasion and deceit. The lapsed even included two prominent ecclesiasts: Cyrus bishop of Nikiu and Victor bishop of the Fayyum, that is, the same turncoat denounced within the Life of Samuel of Kalamon. ${ }^{33}$ The HP names no other bishops. But it nevertheless concludes its report of the persecution with the observation that '[Heraclius] appointed bishops in the lands of Egypt, all of it up to Anșinā [i.e., Antinoe]. ${ }^{34}$ The suggestion here, therefore, is that the new monenergist church stretched throughout the Delta and Arcadia, and even included the capital of the Thebaid.

The opprobrium which the HP directs at Cyrus of Nikiu and Victor of Arsinoe must indicate that each was the Severan incumbent of his respective see. What of their Chalcedonian equivalents? It is difficult to suppose that the new union included rival claimants to the same episcopal thrones, as had existed in the decades before. ${ }^{35}$ Perhaps some Chalcedonian bishops refused the new union; or perhaps during the Persian occupation, when patriarchal oversight was absent and episcopal successions proscribed, the natural deaths of bishops diminished the subsequent dilemma. ${ }^{36}$ Whatever the solution, the reference to Severan defectors points to something quite remarkable: the reintegration of the competing episcopal hierarchies which had existed since the 570s. The Plerophoria, then, should not be seen as the docu-

30 CCP (681) act. (Riedinger vol. 2, 594).

31 So M. Jankowiak, Essai d'histoire politique du monothélisme à partir de la correspondance entre les empereurs byzantins, les patriarches de Constantinople et les papes de Rome, unpublished $\mathrm{PhD}$ thesis, Paris and Warsaw (2009) 89-90. Cf. also the lesser title give to Cyrus in 633/4 in Anonymous Miracles of Cyrus and John 1-3 ed. V. Déroche, 'Un recueil inédit de miracles de Cyr et Jean dans le Koutloumousiou 37', RSBN 49 (2012) 199-220, at 201; and the title of topotērētēs applied to Sergius of Joppa in Jerusalem, at $C$ Later. act. ed. R. Riedinger, Concilium Lateranense a. 649 celebratum, ACO Ser. 2.1 (Berlin, 1984) 46-47.

32 See the letter from Sergius of Constantinople to Honorius of Rome, sent in late 634/early 635, and calling Cyrus patriarch, in CCP (681) act. (Riedinger 534-6).

33 HP (Primitive) (Seybold 98); cf. HP (Vulgate) (Evetts PO 1, 491).

34 HP (Primitive) (Seybold 99); cf. HP (Vulgate) (Evetts PO 1, 492). Cf. the suggestion of John of Nikiu, Chronicle 115, that the Arabs did not encounter opposition to Heraclius for his religious policies until coming to Antinoe.

35 For the establishment of the Severan episcopate see P. Booth, 'A Circle of Egyptian Bishops at the End of Roman Rule (c.600): Texts and Contexts', Mus 131 (2018) 21-72.

36 Ban on episcopal successions: see Copto-Arabic Synaxarium ed. R. Basset, 'Le synaxaire arabe jacobite (rédaction copte)', PO 1, 3, 11, 16, 17 (Paris, 1904-23) at PO 3, $490-491$. 
ment of union between two distinct hierarchies. It was rather the shared manifesto of a single, restored, Alexandrian patriarchate.

The subsequent position of dissenters from the union is difficult to perceive, and it is possible that a faction of less flexible Severan bishops, in particular in the Thebaid, flocked to the figure of Benjamin, who continued to claim the throne of Alexandria. Nevertheless, one suspects that the tradition of Benjamin's flight from persecution - which serves to situate him in the noble tradition of Athanasius and Theodosius - is a pious fiction. It is difficult to suppose that Benjamin would have absented himself from discussions while other prominent Severans negotiated an accord. Indeed in 634, in a heresiological appendix to his synodical letter, Sophronius of Jerusalem - in one of the few non-Egyptian witnesses to Benjamin's actual existence - condemns 'Benjamin of Alexandria and John and Sergius and Thomas and Severus, the Syrians, who are still living their accursed life and waging mad war against piety. ${ }^{37}$ The recognition of Benjamin alongside a series of Syrians is revealing, for these are four of the bishops who accompanied the Severan patriarch Athanasius the Camel-driver in his failed doctrinal discussions with the emperor Heraclius c. 630, when Athanasius aspired to fill the vacant throne of Antioch, but refused the same monenergist compromise later enshrined in the Plerophoria. ${ }^{38}$ Sophronius was himself in Alexandria in June 633, and the association which he makes suggests that Benjamin too had been a leading Severan discussant on monenergism - perhaps even, like Athanasius before him, an aspirant to the vacant patriarchal throne. ${ }^{39}$ It seems better, then, to appreciate Benjamin's 'exile' not as a flight from persecution, but rather as a retreat from a battle for legitimation which he had lost.

Set against this background, later reports of persecution serve an immediate purpose - to excuse the fracturing of the Severan communion in the $630 \mathrm{~s}^{40}$ There is little reason to accept that the Severan bishops who entered upon the union did so under duress, and the unionist spirit belongs to a much wider pattern in the aftermath of the Persian retreat, far beyond the reach of Cyrus. The accusation of persecution which still attaches to him is therefore a gross perversion of his actual in-

37 Sophr. H., ep. syn. in CCP (681) act. (Riedinger vol. 1, 482).

38 For the attempted union see esp. Michael the Syrian, Chronicle 11.1-4 ed. J.-B. Chabot, Chronique de Michel le Syrien (5 vols, Paris, 1899-1910) vol. 4, 403-410); cf. Agapius, Universal History ed. 'Kitab al-'Unvan: Histoire universelle, écrite par Agapius de Menbidj', PO 5, 7, 8, 11, 4 vols (Paris, 1911-15) 467; Chronicle of Seert 88 ed. A. Scher, 'Histoire Nestorienne: Chronique de Séert', PO 4, 5, 7, 13 (4 vols, Paris, 1908-19), at PO 13, 544-545. These sources give the lie to some later accounts (e.g., Thphn., chron. AM 6121) which suggest the realisation of the union after Athanasius's deception of the emperor. For Chalcedonian consternation at Athanasius's potential appointment: see Doctrina Patrum ed. F. Diekamp, Doctrina Patrum de incarnatione Verbi: Ein griechisches Florilegium aus der Wende des 7. und 8. Jahrhunderts (Münster, 1907) 141-148); Antiochus Monachus, Pandects 130 (PG 89 1843BC).

39 Sophronius in Alexandria: CCP (681) act. (Riedinger 538); Max., opusc. 12 (PG 91, 143CD). 40 Cf. below p. 408-410. 
stinct, which was not towards oppression but accommodation. We can demonstrate, moreover, that the same instinct continued throughout his career.

I have suggested above that the references to the Heraclian persecution which pepper the Chronicle of John of Nikiu's account of the period c. 640-c. 644 are later glosses. This is because such statements are otherwise discordant with the Chronicle's central source, which celebrates Cyrus and apologises for his political and doctrinal policies. Alongside his rapprochement with the Severans, Cyrus had also advocated for the appeasement of the Arabs, and negotiated a period of tribute which stretched from c. 636-c. 639. In the late reign of Heraclius (late 639 or 640), however, both policies were reversed, and Cyrus was recalled to the capital, tried, and exiled to North Africa for a brief period, before his restoration at the hands of Heraclonas, Heraclius's son, in the summer of $641 .{ }^{41}$ Upon his arrival at Alexandria - which the Chronicle, or rather its source, presents as the cause of universal celebration - Cyrus had first retreated to a 'church of the Theodosians' and thence to a 'monastery of the Theodosians' where he retrieved a cross given to him before his exile. His first action, therefore, was to reaffirm his alliance with those Severans with whom he had entered into union in 633. He then processed through to celebrate the Festival of the Cross, as joyous, chanting crowds accompanied him - the image of the hated persecutor, therefore, here seems quite distant. ${ }^{42}$

During the patriarch's exile, it is evident that the doctrinal entente realised in the union of 633 had begun to fracture, as Heraclius had retreated from the unionist policies of the period following the Persian withdrawal. But such was the work of Cyrus's enemies. Before describing the patriarch's return in September 641, the Chronicle sets out a series of political rivalries, and associated violence, which were active in Alexandria in the summer of 641, in particular between the allies of one Menas and those of a Domentianus. The tensions are in part attributed to an unspecific conflict over 'the faith,' and there are indeed several indications that Domentianus was an opponent of Cyrus's doctrinal initiatives within the 630s. Above all, it is Domentianus's brother, Eudocianus, who is said to have perpetrated certain outrages against the orthodox at Easter 641 - which the Chronicle's source presents as the proximate cause of Roman defeats in the field - and to have angered Menas through that same violence. It is striking, therefore, that upon his return, Cyrus elevated Menas and banished Domentianus - an emphatic reaffirmation of his commitment to the Severans, and a fundamental correction to the patriarch's later, somewhat tragic, construction as an unambiguous persecutor. ${ }^{43}$

41 For all this see Booth (cf. fn. 18).

42 See John of Nikiu, Chronicle 120 (Zotenberg 211-212). Note the unfortunate decision of Zotenberg, Chronique 454 and R. H. Charles, The Chronicle of John, Bishop of Nikiu (London, 1916) 192-193 to render the Ethiopic tā'odosāwyān as 'Tabionnesiotes' or 'monks of Tabenna.'

43 See John of Nikiu, Chronicle 119-120, with Booth (cf. fn. 18) 539-550 for a full account. 


\section{The Church of the Persecuted}

We should not suppose that the advent of Arab rule was an unambiguous triumph for the Severans, or that Severan bishops dominated from the outset. It is true that the Chalcedonian patriarchate seems to have been dissolved after the reign of Peter (642-652/3), appointed to succeed Cyrus after the latter's death in March 642. ${ }^{44}$ But Chalcedonism remained strong, at least in Alexandria, into the 680s, and elsewhere too the various factions of the last phase of Roman rule must have remained - not least, the monenergist bishops who had entered into union in $633 .{ }^{45} \mathrm{~A}$ dearth of evidence means we cannot gauge the relative strength of the different groups (that is, the number of their bishops, their degree of popular support, and their geographical distribution) but it is certain that monenergism cast a long shadow over the Arab period. Even the HP describes how the patriarch Benjamin, after his restoration, through polite encouragement and consolation 'drew to himself most of the people whom Heraclius had led astray as heretics,' that is, those who had communed with the monenergist church in the 630s. Benjamin, we are told, invited the lapsed bishops to return, and some did so with 'copious tears'; however others, through shame of their denial of the faith, refused, 'and remained in their heresy until they died. ${ }^{46}$

Some of the texts credited to Benjamin himself are, as we shall see, products of later generations. ${ }^{47}$ But two festal letters - which have numerous parallels in theme and content ${ }^{48}$ - seem in fact to come from his pen, and to confirm the picture of the HP. The first, a 16th Festal Letter (thus 642), is attributed to the patriarch in a single Ethiopic manuscript. The author claims that some more extreme opponents (perhaps the Gaianites?) have, as a consequence of his earlier refutation of theopaschism, accused him of Chalcedonism. In response, and with recourse to a rich repertoire of patristic citations (including Dioscorus and Severus), the author offers a robust defence of God's impassible suffering in the flesh, refuting both Nestorius and Apollinarius, criticising the Chalcedonian 'two natures,' and culminating in a proclamation

\footnotetext{
44 Appointment: John of Nikiu, Chronicle 121 (Zotenberg 219). For the suggested end of the patriarchate, see the patriarchal lists in Thphn., chron. AM 6136-6145 (= 644/5-653/4); Nicephorus, Chronographia (de Boor 129); and cf. CCP (681) act., where we find no Alexandrian patriarch (as for Constantinople and Antioch), nor even a representative of the patriarch (as for Rome and Jerusalem), but a priest and monk Peter, called nothing more than 'representative (topotērētēs) of the apostolic see of the great city Alexandria' (e.g., Riedinger 20). For his predecessor Theodore in 662 see ibid. 230. 45 For Chalcedonism at Alexandria see HP (Primitive) (Seybold 112-113); HP (Vulgate) (Evetts PO 5, 5-6); Anastasius of Sinai, Hodegos 10.1-4 ed. K.-H. Uthemann, Anastasii Sinaitae Viae Dux (Turnhout, 1981) 143-194, with P. Booth, 'Debating the Faith in Early Islamic Egypt', JEH 70 (2019) 691-707. 46 HP (Primitive) (Seybold 101); HP (Vulgate) (Evetts PO 1, 497).

47 See below p. 408-409.

48 For the parallels see C. Römer in P.Köln V 215, 84-85.
} 
of one hypostasis, one nature, and one operation. ${ }^{49}$ There is, then, no explicit engagement with the issue of monenergism, and theopaschism is a perennial Christological problem. But it is not impossible that the new traction of the issue resulted from the perception that the Word's suffering was the most pertinent example of his single energeia.

In the second letter the issue of monenergism is far more prominent. This incomplete text, extant on papyrus and dated to the seventh century on palaeographical grounds, is also concerned with theopaschism and Apollinarianism, but is here far more concerned with monenergism and its doctrinal successor monotheletism the doctrine of Christ's single will, supported at Constantinople, in one form or another, from c. 638. Due to a large number of lacunae in the letter, the author's precise position on both doctrines is uncertain, but it has been demonstrated that he had access to a florilegium of monenergist and monothelete citations, which also circulated within the east Roman empire. The placement of Easter on April 2nd demands 663 or 674 , so that the letter might belong to Benjamin's successor, Agathon, rather than Benjamin himself. ${ }^{50}$ But it nevertheless proves that the issue of monenergism remained live in Severan circles long after the end of Roman rule, and that it seems to have become more pertinent, from the Severan perspective, after the conquest. It is difficult not to perceive in both letters an attempt to reconcile monenergist bishops, while also reassuring Severan critics of Chalcedon that the doctrine of the single operation resulted neither in Nestorianism nor in Apollinarianism.

It is from this context, I suggest, that the narrative of Benjamin's flight and Heraclius's persecution first took seed. We have seen that this tradition distorts the complexities of the 630s, and is a gross perversion of the efforts made towards rapprochement. But in the post-conquest period, when the dissolution of the Chalcedonian patriarchate presented new opportunities for the reintegration of the Severan communion, traditions of persecution (through blandishment, threat, or violence) provided the requisite cover not only to explain the previous fragmentation of the emergent Severan Church, but also to reintegrate monenergist bishops within it. Whether this tradition was propagated before the late seventh century is uncertain, but it soon gained a momentum of its own, in particular as different communities attempted to write themselves into the tale of Benjamin's flight. Thus one extant text ascribed to the patriarch - On the Marriage at Cana ${ }^{51}$ - repeats, in its current

49 Ed. C. D. G. Müller, Die Homilie über die Hochzeit zu Kana und weitere Schriften des Patriarchen Benjamin I. von Alexandrien (Heidelberg, 1968) 302-351.

50 See P. Köln V 215, with U. Hagedorn and D. Hagedorn, 'Monotheletisch interpretierte Väterzitate und eine Anleihe bei Johannes Chrysostomus in dem Kölner Osterfestbrief (P. Köln V 215)', ZPE 178 (2011) 143-157.

51 On Cana: ed. (Sahidic) Müller (cf. fn. 49) 52-285 (with ibid. 39-49 for the Bohairic and Arabic versions). The homily survives in two parts. The first part has few historical markers, but does contain a section in which the author denounces various Judases, including 'the criminal' Cyrus and a Victor (of Fayyum?) (Müller 84) - it is possible that this is authentic. The second part consists of three spi- 
form at least, the narrative framework contained within the $H P$, and bear signs of being a product of the White Monastery, which is inserted into the tradition of the patriarch's flight and exile; ${ }^{52}$ another, an incomplete letter also attributed to the patriarch, inserts the bishops of Babylon and 'Halouan' (i.e., Hulwān, in fact a foundation of 'Abd al-'Aziz [685-705]) ${ }^{53}$ into the same tradition, reflecting later realities; ${ }^{54}$ and the so-called Consecration of the Church of Saint Macarius attributed to Agathon - which Mawhūb b. Manșūr has added to the HP, but which also survives in a full version in Bohairic and Arabic - describes Benjamin's consecration of a church at Scetis, following the end of persecution, and is eager to emphasise the role of its monasteries in harbouring him..$^{55}$ Such texts have often been used in tentative reconstructions of Benjamin's corpus and career. ${ }^{56}$ But it is better to approach them as later contributions to his legend, as Severan communities adopted and expanded a now foundational narrative.

The same process operates, I suggest, within the Life of Samuel of Kalamon which, as we noted above, was produced several generations after the lifetime of its hero. The attentive reader might have noted that the enforcement of Leo's Tome is there attributed to 'Justinian, false king of the Romans,' and not to Heraclius. This mistake is more than a scribal error, since it reveals to us the author's source. For readers of Coptic literature, the encounter between the sainted ascetic and the corrupt magistrianus bearing the Tome is a familiar scene, for it also occurs, in similar format, in the Coptic Life of Longinus (set under Marcian) ${ }^{57}$ and in the Coptic and Ethiopic versions of the Life of Daniel of Scetis (set under Justinian). ${ }^{58}$ Indeed the parallels between the Life of Samuel and the Life of Daniel are so close as to suggest the direct dependence of the former upon the latter - hence the accidental transmission

ritual tales about Benjamin, which must be later addenda. One has a separate transmission, in Paris copte $129^{14} 122 r-123 v$ ed. C. D. G. Müller, 'Neues über Benjamin I, 38. und Agathon, 39. Patriarchen von Alexandrien', Mus 72 (1959) 322-47, at 337-339.

52 (Ps.-)Benjamin, On the Marriage at Cana (Müller 134, 138, 146, 218, 238). See also the homily On Shenoute attributed to Benjamin, ed. (from Paris copte $129^{14}$ ff. 123v-124v) Müller (cf. fn. 51) 339-341; repr. id. (cf. fn. 49) 286-294.

53 See below fn. 73.

54 Ed. E. Amélineau, 'Fragments coptes pour servir à l'histoire de la conquête de l'Égypte par les Arabes', JA Ser. 812 (1888) 361-410, at 368-378.

55 See the redactional note at HP (Primitive) (Seybold 104) HP (Vulgate) (Evetts PO 1, 503), with den Heijer, Mawhūb b. Manșūr b. Mufarriğ 144-145. For the independent versions see R.-G. Coquin, Livre de la consécration de Benjamin (Cairo, 1975).

56 See esp. Müller (cf. fn. 9).

57 Life of Longinus 29-37 ed. T. Orlandi, Vita dei monachi Phif et Longino (Milan, 1975) 78-88. The anti-Chalcedonian section has an independent transmission in Ethiopic, and seems to be a later addition; see S. Grébaut, 'La Prière de Langinos', ROC 15 (1910) 42-52.

58 Coptic: ed. I Guidi, 'Vie et récits de l'Abbé Daniel de Scété (vi siècle)', ROC 5 (1900) 535-552, at 548 - 550. Ethiopic: ed. L. Goldschmidt and F. M. Esteves Pereira, Vida do Abba Daniel do Mosteiro de Sceté: Versão Ethiopica (Lisbon, 1897) at 23-25. 
of the name of Justinian. ${ }^{59}$ What this suggests, therefore, is that the author is not so much describing an historical event as repurposing an accepted hagiographic scene, situating Samuel within a wider narrative of Severan resistance in which the monks of Kalamon now participate.

\section{Images of Emperors and Emirs}

If the image of the last Roman emperor propagated in Coptic literature functions to create a shared past of persecution for the Severan Church, then within that corpus of texts in which we first encounter that image, at the turn of the seventh and eighth centuries, it also functions as a foil for the new Arab governors. Thus according to the concluding section of the Chronicle of John of Nikiu, soon after the withdrawal of Roman forces from Alexandria (placed on 20th September 642), two figures entered Alexandria in rapid succession: first, 'Amr b. al-'Āṣ, the triumphant Arab general; and second, Benjamin, the Severan patriarch and erstwhile exile in the south (c. 643/4?). ${ }^{60}$ The Chronicle then reports that supposed popular perception that the oppression of the emperor Heraclius and his tormenting of the orthodox at the hand of the patriarch Cyrus' were the cause of Roman defeat; but it then at once notes of 'Amr that 'He took the amount of tribute which they determined and took nothing from the property of the church, and engaged in no plunder or pillage. He protected them for the whole length of his reign. ${ }^{61}$ The contrast with Heraclius is obvious.

A more fulsome account of Benjamin's return, in which 'Amr assumes a much more prominent part, is recounted in the HP. Following 'Amr's entrance into Alexandria, the HP reports, 'Senouthios the believing $d u x$ ' - who is a real historical actor, appointed $d u x$ of the Thebaid after the conquest ${ }^{62}$ - informed the general of Benjamin's situation, and 'Amr sent out a letter summoning the patriarch to return from his exile and to resume control of his church. Thereupon Benjamin entered in triumph into Alexandria, and at an audience with 'Amr, who received him with honour, he even prayed for, and predicted, the Arab conquest of Pentapolis, assuming the

59 For the parallels see T. Vivian et al. Witness to Holiness: Abba Daniel of Scetis (Kalamazoo, MI, 2008) 336-341, fn. 35, 102-103.

60 See John of Nikiu, Chronicle 120-121 (Zotenberg 219-220). Benjamin's exile is said to have been for thirteen years, but note that the rubric at ibid. (Zotenberg 26) calculates fourteen years. Soon after describing Benjamin's return, the Chronicle notes the coming to Alexandria of John of Damietta, 'in the second year of the lunar cycle' (Zotenberg 220). Although other such references seem to indicate the Alexandrian lunar cycle, it is probable that that this intends the indiction, thus 643/4; see P. Booth, 'The Muslim Conquest of Egypt Reconsidered', in C. Zuckerman (ed.), Constructing the Seventh Century, TM 17 (2013) 639-670, at 643 fn. 15.

61 John of Nikiu, Chronicle 121 (Zotenberg 220).

62 See BGU I 323 (14.vi.653). Note the appearance of Senouthios also in (Ps.-)Benjamin, On the Marriage at Cana (Müller 174-176), which perhaps here depends upon the HP. 
role of a philosopher-cum-prophet at court. ${ }^{63}$ In both recensions of the text, the return of Benjamin from his exile not only signifies the fulfilment of the divine fates of both general and patriarch, but also marks a new, emphatic collaboration of the Severan church and its Arab conquerors. But in the earlier recension, the socalled 'Primitive,' this scene marks the denouement of a longer narrative, in which 'Amr invades in order to liberate the orthodox from 'Roman' oppression. ${ }^{64}$ There is no need to accept this same tradition - which the later 'Vulgate' recension of the $H P$ has chosen to expunge, but which is echoed in later Syriac and in Islamic literature $^{65}$ - as historical. But it demonstrates how an emphasis on Roman persecution (and, with it, on Arab toleration) served also to sanction the collaboration of the Severan patriarchs with the new regime.

Within George the Archdeacon's compilation of Lives within the HP, this co-operation of patriarch and conqueror serves also to predict and to model the political position of Benjamin's successors. ${ }^{66}$ Thus in a series of Lives which embrace the governorship of 'Abd al-'Aziz (685-705), and which form the conclusion to George's compilation, the text celebrates the close collaboration of governor and patriarch, and the flourishing of the church under the patronage of 'Abd al-'Aziz and his two Severan secretaries, the Edessene Athanasius bar Gūmōyē and the Egyptian Isaac. ${ }^{67}$ According to the HP's account of the career of John III (681-689), 'Abd al'Azīz, at first persecuted, but then patronised, the patriarch. It claims that John - reprising the role of Benjamin - impressed the governor at an audience, and then flourished under his and his secretaries' protection, rebuilding and endowing the Church of Saint Mark in Alexandria, and welcoming Chalcedonian communities into the Sev-

63 HP (Primitive) (Seybold 101); HP (Vulgate) (Evetts PO 1, 495-497).

64 See HP (Primitive) (Seybold 99), with J. Den Heijer, 'La conquête arabe vue par les historiens coptes', in C. Decobert (ed.) Valeur et Distance: Identités et sociétés en Égypte (Paris, 2000) 227245, esp. 231.

65 Chronicle to 1234118 ed. J.-B. Chabot, Chronicon anonymum ad annum Christi 1234 pertinens (2 vols, Leuven, 1916-20) vol. 1, 251-252; Michael the Syrian, Chronicle 11.8 (both drawing from Dionysius of Tel Maḥre); b. 'Abd al-Ḥakam, Futūḥ Miṣr ed. C. Torrey, Futūḥ Miṣr wa-akhbāruhā (New Haven, CT, 1922) 58.

66 So also M. Swanson, 'Reading the Church’s Story: The "'Amr-Benjamin Paradigm” and Its Echoes in the History of the Patriarchs of Alexandria', in N. van Doorn-Harder (ed.), Copts in Contexts: Negotiating Identity, Tradition, and Modernity (Columbia, SC, 2017) 157-168.

67 On the secretaries see Mena of Nikiu, Life of Isaac (Porcher 358-362); HP (Primitive) (Seybold 116, 122, 135); HP (Vulgate) (Evetts PO 5, 12, 48-49, 54); Eutychius, Annals (Antiochene Recension) ed. L. Cheiko, Eutychii patriarchae Alexandrini Annales (2 vols, Beirut, 1906-9) 41; Ps.-Abū Șāliḥ, Churches and Monasteries of Egypt ed. B.T.A. Evetts, Churches and Monasteries of Egypt and Some Neighbouring Countries (Oxford, 1895) fol. 53a; Michael the Great, Chronicle 11.16; Chronicle to 1234 149; al-Kindī, Kitāb al-Wūlat ed. R. Guest, The Governors and Judges of Egypt (Leiden, 1912) 59; perhaps also B. 'Abd al-Ḥakam, Futūh Misr (Torrey 98); P.Lond. IV 1412, 1447; Anastasius of Sinai, Hodegos 6.1.120 -121, 10.1.2.36-37. On Athanasius and the Gūmōyē see M. Debié, 'Christians in the Service of the Caliph: Through the Looking Glass of Communal Identities', in A. Borrut and F. M. Donner (eds), Christians and Others in Umayyad State (Chicago, IL, 2016) 53-71. 
eran communion. ${ }^{68}$ The interaction of John and 'Abd al-'Azīz indeed became legend, since it is also memorialised in a disputational text, the so-called Controversy of John. Extant in several Coptic fragments and a full Arabic version, this text recounts how, at an audience with 'Abd al-'Azìz, John purchased a fragment of the True Cross left in the estate of an intestate Jew; defeated and converted a Chalcedonian and a Jew in a debate; and defended the real presence in the eucharist. ${ }^{69}$ It is impossible to ascertain if the text describes a real event, which seems improbable (the Arabic version's description of 'Abd al- 'Azīz as 'the same who built the Nilometer at Hulwān,' if original to the text, suggests some distance from his death in 705). But the author at least recreates two contexts which appear authentic: first, the close collaboration of John and 'Abd al-'Aziz; and, second, the disputational culture of the governor's court. ${ }^{70}$

The HP's Life of John makes much of the fact that during his patriarchate, John had designated as his successor one Isaac, a monk at Scetis, and the spiritual son of the bishop Zacharias (of Saïs/Sā). ${ }^{71}$ The reason for this emphasis becomes evident when the HP transitions to its Life of Isaac, which claims that upon John's death, a group of prominent bishops - which includes John of Nikiu - attempted to consecrate a deacon George, without the approval of the governor. When 'Abd al-'Aziz then summoned the bishops and discovered that their candidate was not John's choice, he was angered and instead ordered the consecration of Isaac. ${ }^{72}$ The HP of course presents all this as the realisation of God's will, but the whole scene seems designed to obfuscate an uncomfortable fact - that 'Abd al-'Azìz could now determine the election of the Severan patriarch, to the extent of being able to refuse the collective nominee of the bishops. Indeed, the consistent leitmotif of the HP's Life of Isaac is the orientation of ecclesiastical affairs around 'Abd al-'Azìz. Thus in successive anecdotes the HP notes how Isaac built a church at Hulwān, the governor's new foundation to the south of Fusțāt, where he attended upon the governor; ${ }^{73}$ and how 'the secretaries' (Athanasius and Isaac?) were forced to intervene when certain 'intriguers'

68 HP (Primitive) (Seybold 119); HP (Vulgate) (Evetts PO 5, 13-19). The Chalcedonian communities named are the اهل اغرو / اهل اغروة and the اهل اسخطس / اهل سخيطس, i.e., the peoples of Agarwa and of Sahịțus/Ashanțus. Their identification is however unclear; cf. S. Timm, Das christlich-koptische Ägypten in arabischer Zeit (7 vols, Wiesbaden, 1984-92) 75-76, 2238-2239.

69 Ed. (Coptic) H. G. Evelyn-White, The Monasteries of the Wadi 'n Natrûn (3 vols, New York, 19261933) vol. 1, 171-175. There the editor also describes the Arabic versions, which are unedited but contained in Paris BN Ar. 215 and 4881.

70 On this culture, in which Anastasius of Sinai participated, see also Booth (cf. fn. 45).

71 HP (Primitive) (Seybold 119); HP (Vulgate) (Evetts PO 5, 19).

72 HP (Primitive) (Seybold 120); HP (Vulgate) (Evetts PO 5, 22-24).

73 On Hulwān see Timm (cf. fn. 68) 1074-1078; W. B. Kubiak, "Abd al-'Azīz b. Marwan and the Early Islamic Building Activity and Urbanism in Egypt', Africana Bulletin 42 (1994) 7-19. On its palace complexes see P. Grossmann, Christliche Architektur in Ägypten (Leiden, 2002) 417-419, who identifies Palace A with the Severan patriarchal palace. 
denounced the patriarch to 'Abd al-'Azìz for his attempts to mediate a dispute between the Ethiopians and Nubians. ${ }^{74}$

The patriarch Isaac presents an unusual case, for besides the HP there also survives an extensive Life of Isaac, extant in a single Coptic manuscript, attributed to the bishop Mena of Nikiu, ${ }^{75}$ a former monk of Scetis and the chronicler John's successor in his see. ${ }^{76}$ Mena was appointed in the period c. 697-c. 700, under the patriarch Simon (c. 692-700), ${ }^{77}$ and the Life cannot date much later than that time. ${ }^{78}$ The Life contains several sections which intersect with the Life of Isaac as contained within the $H P$, and the relation of the texts does not seem to be one of simple dependence in one direction or the other. Sometimes Mena's Life seems to summarise the $H P, 7^{79}$ but in other places it offers divergent, more elaborate accounts of an episode which the HP appears to epitomise. ${ }^{80}$ It is not impossible, therefore, that the two accounts depend upon a shared source. But much within Mena's text is unique.

At one point, the text makes pointed reference to a priest and confessor, Joseph, 'who was stood before the tribunal of the impious Cyrus, and who received a great number of blows on account on his confession of the faith. ${ }^{81}$ But for the most part it presents a more glorious present, in which the Severan church flourished under the patronage of the authorities at Fusțāt. First amongst these were the two Severan secretaries, Isaac and Athanasius. It is claimed that while still an ascetic at Scetis, Isaac received a revelation concerning the former; ${ }^{82}$ whereas Athanasius is said first to have opposed the patriarch but, when Isaac had healed his ailing son, to have become an active patron, funding the restoration of the Angelion, the Severans' cathedral church at Alexandria. Indeed, their fortunes at Alexandria seem now to have been reversed. The text notes that, for the first time, the so-called 'One Hundred' were able to meet at Alexandria, and while the meaning of this is not explicit, it seems to indicate that a synod of all Severan bishops was now able to convene. ${ }^{83}$

74 For both see HP (Primitive) (Seybold 121); HP (Vulgate) (Evetts PO 5, 24-25).

75 Ed. Porcher, 'Vie d'Isaac'.

76 See HP (Primitive) (Seybold 125); HP (Vulgate) (Evetts PO 5, 34).

77 See D. N. Bell, Mena of Nikiou: The Life of Isaac of Alexandria \& The Martyrdom of Saint Macrobius (Kalamazoo, MI, 1988) 27.

78 See, for example, Life of Isaac 3 (Porcher 312) which calls Zacharias - the future bishop of 'Sai' (= Saïs/Sā) who died under John III (Life of Isaac 10) - 'of good memory,' and which, at ibid. 9 (Porcher 341) describes a living bishop of the same see, Orion, who is in all likelihood Zacharias' immediate successor.

79 See esp. Life of Isaac 11 (Porcher 346-348).

80 See esp. Life of Isaac 11 (Porcher 348-353), on Isaac's contested election; and Life of Isaac 11 (Porcher 377-384), on affairs with the Nubians. Cf. HP (Primitive) (Seybold 120-121); HP (Vulgate) (Evetts PO 5, 22-25).

81 Life of Isaac 3 (Porcher 345).

82 Life of Isaac 8 (Porcher 334-335). Cf. Life of Isaac 11 (Porcher 347, 351).

83 Life of Isaac 12 (Porcher 358-363). 
The reasons for Athanasius's initial opposition are not given - but it is possible that the text is modelling the appropriate attitude of Christian officials to the patriarch, mirroring and anticipating that of the church's most important patron, the governor 'Abd al-'Azīz, whom the Life calls 'the king (pouro),' the former designation of the Roman emperor. In contrast to the HP, the Life reduces the role of the governor in Isaac's appointment, instead presenting him as the preferred candidate of most bishops. ${ }^{84}$ But it nevertheless proceeds to a series of anecdotes which celebrate the close relations of patriarch and governor. Some of these serve to confirm the former's holiness before the latter: a miraculous light surrounds Isaac at the altar; an entourage of angels surrounds him in his chamber; and he heals the sick son of the governor's relative. The result, according to Mena, was that 'the king' included Isaac in his permanent entourage; began to call Isaac 'prophet' and 'patriarch' (in the Biblical sense); and built churches and monasteries in 'Alban/Halban' (i.e., Hulwān) - 'for he loved the Christians. ${ }^{85}$

In two other episodes, Isaac faces some serious trial before 'Abd al-'Azìz. In the first, some Arabs accuse the patriarch of hating them and their faith, so that the governor commanded his secretaries summon Isaac to dinner, but forbid him from making the sign of the cross over his food, on pain of death. Isaac then attends a feast at which the governor presides, but through a ruse nevertheless makes the sign without being detected, leading 'Abd al-'Azīz to proclaim his great wisdom, and to reaffirm his status as prophet and patriarch. Isaac is compared to 'the prophet Daniel before the kings of the Chaldeans and the Persians,' and the whole episode - in which certain detractors denounce a sainted prophet before a foreign king, and in which the former survives his subsequent trial - is modelled on the Book of Daniel. ${ }^{86}$ It serves both to establish an irreducible divide between 'Abd al-'Azìz and the patriarch, while also hanging their evident closeness on the governor's humble recognition of the patriarch's holiness.

In the second episode (also recorded, in passing, in the $H P)^{87}$ the governor again threatens Isaac with execution when the latter intervenes in the politics of the Nubian kingdoms, attempting to make peace between the Christians of Maurotania (at peace with the Saracens) and those of Makouria (not at peace). 'Abd al-'Aziz then summoned the patriarch to the praetorium at Babylon, but is dissuaded from executing him when Isaac enters with two celestial companions, later revealed as saints Peter and Mark. 'For this reason o king,' the patriarch proclaims, 'take care over the Church, and do not afflict it. For in truth, he who afflicts the Church has afflicted God.' The scene, therefore, serves once again to underline both the patriarch's holi-

84 See Life of Isaac 11 (Porcher 348-353).

85 See Life of Isaac 13 (Porcher 363-372, quotation at 368).

86 See Life of Isaac 13 (Porcher 372-377, quotation at 376).

87 See above fn. 74. 
ness and the benefits of co-operation. It concludes with 'Abd al-'Azìz commanding the patriarch to build a church at Hulwān. ${ }^{88}$

We possess no equivalent Life of Isaac's successor Simon, and must depend again upon the HP, and the last of the biographies within George the Archdeacon's compilation. In its transition between its Life of Isaac and Life of Simon, the HP describes another complex succession, in which 'Abd al-'Azìz passes over the eventual choice of the Alexandrians, the archimandrite of the Ennaton, and instead commands the appointment of his spiritual son Simon, a Syrian - perhaps because he desired to build bridges with the Severans of Antioch, as then described within the text. ${ }^{89}$ Simon, it seems, was an unpopular patriarch who nevertheless had the active patronage of 'Abd al- 'Aziz. ${ }^{90}$ Perhaps the most striking example of that patronage is a strange episode (placed in 695, soon after the Roman coup against Justinian II) in which the governor gathered to Hulwān sixty-four Severan bishops, as well as an unspecified number of heretical bishops - including the Chalcedonian Theophylact, the Gaianite Theodore, and the Barsanuphian George -, and upbraided them for their division. The HP gives a vague account of the affair, in which the other bishops proclaim Simon closest to their own position, and Simon himself denounces all the others. ${ }^{91}$ But it seems that this gathering lasted for no less than three years (c. 697-c. 700). ${ }^{92}$ At the end of that time, 'Abd al-'Azīz then released the bishops to their sees, but not before he commanded them to build two churches at Hulwān. ${ }^{93}$ The suggestion seems to be, therefore, that the Severan bishops emerged unscathed from their long presence in Hulwān, and with an expanded presence in 'Abd al-'Azīz's capital.

The compilation of George the Archdeacon therefore aligns with other Severan texts produced within the same circle - in particular, the Chronicle of John of Nikiu and Mena's Life of Isaac. On the one hand, each embeds an image of the emperor Heraclius, and his patriarch Cyrus, as a violent persecutor; but each also cre-

88 See Life of Isaac 13 (Porcher 377-385, quotation at 384). For the patriarch's building at Hulwān cf. Ps.-Abū Șālih, Churches and Monasteries of Egypt, fol. 53a.

89 HP (Primitive) (Seybold 122-124); HP (Vulgate) (Evetts PO 5, 25-30).

90 See the report of popular hatred towards Simon, the attempt of certain clerics to poison him, and 'Abd al-'Azìz's public burning of some of the perpetrators - HP (Primitive) (Seybold 124-125); HP (Vulgate) (Evetts PO 5, 30-32).

91 HP (Primitive) (Seybold 126-127); HP (Vulgate) (Evetts PO 5, 34-36). It seems to be placed at Hulwān at HP (Primitive) (Seybold 127); HP (Vulgate) (Evetts PO 5, 37).

92 The episode fulfils a reported curse of John of Nikiu, upon his penance for violence against a monk, that 'the Lord God, whose name I know, shall make all of you, o bishops, strangers from your sees until the end of the period to which you have condemned me'; see HP (Primitive) (Seybold 127); HP (Vulgate) (Evetts PO 5, 33-34). At HP (Primitive) (Seybold 129); HP (Vulgate) (Evetts PO 5, 42), following an episode in which 'Abd al-'Azīz accuses the patriarch (like Isaac before him) of improper interactions with 'the Indians' (the Ethiopians?), the text states: 'After three years he ['Abd al-'Aziz] released the bishops to their sees....' On the internal indications of the HP, John of Nikiu's deposition must have occurred c. 697.

93 HP (Primitive) (Seybold 129); HP (Vulgate) (Evetts PO 5, 42). Cf. Ps.-Abū Ṣālih, Churches and Monasteries of Egypt fol. 53a. 
ates an implicit contrast with the subsequent toleration of an Arab governor, whether 'Amr b. al-'Āṣ or 'Abd al-'Azīz b. Marwān. We have seen that the presentation of the last phase of Roman rule as a period of persecution is a distortion, designed to disguise the actual complexities of the 630s, and to provide the conceptual space in which to integrate and enlarge the Severan communion. But that presentation also served to legitimise a tentative transference of the model of the good ruler from Christian to Muslim - from a Roman who had fallen from, to an Arab who had fulfilled, the requisite ideals of recognising, patronising, and protecting the orthodox. The two images are therefore inseparable, and one should not be discussed in isolation from the other.

\section{Conclusion}

Three artefacts. The first is a glass dīnār weight once in the private collection of A. $\mathrm{H}$. Morton. It is inscribed with the legend, 'Of 'Abd al-'Azìz, the Amīr. Weight, fullweight,' and weighs 4.29 grams. $^{94}$ The second is a bronze coin which seems to have been minted at Fusțāt. It carries the image of a bearded man, and on the reverse bears, in the exergue, the Greek legend ABAZ. ${ }^{95}$ The third is a Greek-Arabic protocol preserved in the Bodleian, Oxford. Almost all of the Arabic is lost, but the Greek retains the title Abd[elaziz huios] Marou[an symboulos]. ${ }^{96}$

These artefacts each speak to a changing world. The dīnār weight can be dated with some precision, for it serves the reformed gold coinage of 'Abd al-'Azīz's brother, the caliph 'Abd al-Malik, which abandoned Roman and Sasanian motifs, and instead instituted, from 696, a radical, aniconic coin weighing 4.25 grams, and including the šahada and an anti-Christian quotation from the Qur'ān (Q 112:1-4). ${ }^{97}$ The bronze coin is not part of that same caliphal programme, but nevertheless points to the same reformist spirit, for the figure, though based upon the facing bust of a Roman emperor (Constans II), is denuded of Christian signs and appears to depict

94 A. H. Morton, 'A Glass Dīnār Weight in the Name of 'Abd al-'Azīz b. Marwān', BSOAS 49 (1986) 177-182.

95 See, e. g., L. Domaszewicz and M. L. Bates, 'Copper Coinage of Egypt in the Seventh Century', in J. L. Bacharach (ed.), Fustat Finds: Beads, Coins, Medical Instruments, Textiles, and Other Artifacts from the Awad Collection (Cairo, 2002) 88-111, at 97, 110 no. 29; with the critical comments of M. A. Metlich and N. C. Schindel, 'Egyptian Copper Coinage in the 7th Century: Some Critical Remarks', Oriental Numismatic Society Newsletter 179 (2004) 11-14, esp. 13-14.

96 P.GrohmannPapyrusprotokoll 3 = A. Grohmann, 'Zum Papyrusprotokoll in früharabischer Zeit', JÖBG 9 (1960) 1-19, at 13-14.

97 See, e.g., L. Treadwell, “Abd al-Malik's Coinage Reforms: The Role of the Damascus Mint', $R N 165$ (2009) 357-381; S. Heidemann, 'The Evolving Representation of the Early Islamic Empire and Its Religion on Coin Imagery', in A. Neuwirth et al. (eds), The Qur'ān in Context: Historical and Literary Investigations into the Quranic Milieu (Leiden, 2010) 149-195, at 184-186. 
an Arab - equivalent to the 'standing caliph' coinage of 'Abd al-Malik, ${ }^{98}$ or the 'orans drachm' of Bišr b. Marwān. ${ }^{99}$ Indeed, it perhaps portrays another of their siblings, for the reverse legend $A B A Z$ is best explained as an abbreviation not of an obscure or corrupted mint, but rather of 'Abd al-'Azīz. ${ }^{100}$ The final item, the Greek-Arabic protocol, is one of several extant from the reign of 'Abd al-'Azìz, and is representative of the first intrusion of Arabic into official protocols and entagia. ${ }^{101}$ Our three artefacts, then, are indicative of important reforms which occurred under 'Abd al-'Azīz. But numismatic change and the heightened intrusion of Arabic into public culture are part of a still wider transformation: under 'Abd al-'Azīz, for example, people bearing Arabic names appear, for the first time, as duces and pagarchs; ${ }^{102}$ agri deserti are reassigned in an attempt to maintain fiscal revenues in the face of evident fugitivism; ${ }^{103}$ and the first Arab estate is documented outside of Fusțāt. ${ }^{104}$ Such changes, of course, drew from existing trends; ${ }^{105}$ and important questions remain around the extent to which 'Abd al-'Azīz should be seen as a willing participant in the comparable, centralising programme of his brother. ${ }^{106}$ But for our purposes, we can note that the world outside of Severan texts - with their laser focus on a limited number of affairs at the highest levels - was transforming.

It seems indisputable that the fortunes of the Severan church improved under 'Abd al-'Aziz, as the Chalcedonians fell into confusion and schism - following the Sixth Ecumenical Council's dramatic abandonment of monenergism and monotheletism in 680/1 - and as the Severans leveraged the support of the governor's two

98 Treadwell (cf. fn. 97) 13-16; Heidemann (cf. fn. 97) 170-184.

99 See L. Treadwell, 'The “Orans” Drachms of Bishr b. Marwān and the Figural Coinage of the Early Marwanid Period', Oxford Studies in Islamic Art 9 (2001) 223-269. One known example bears the name Bišr b. Marwān, governor of Iraq and 'Abd al-'Azīz's brother.

100 See Metlich and Schindel (cf. fn. 95) 13-14; C. Foss, Arab-Byzantine Coins: An Introduction, with a Catalogue of the Dumbarton Oaks Collection (Washington, D.C., 2008) 102-104.

101 For protocols see, e.g., P.Gascou 27a (694/5) 27b; SB III 7240 (= P.BellTwoLetters 1; 697); Corpus Papyrorum Raineri III 1-11 (685-705); P.CLT 1 (698). For these texts and for P.Ness. 60a = P.GrohmannPapyrusprotokoll 2a (674), which Grohmann supposed to have a bilingual protocol, see Delattre and Vanthieghem in P.Gascou 27 116. On the five known bilingual entagia of 'Abd al-'Azīz see A. Delattre at al., 'Un entagion bilingue du gouverneur 'Abd al-'Azīz b. Marwān trouvé à Antinoé', CE 88 (2013) 363-371.

102 See below fn. 115.

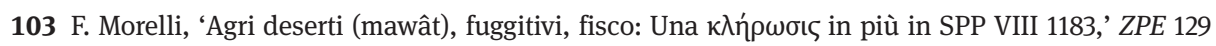
(2000) 167-178 (citing also CPR 76-78, from the Atias archive).

104 See CPR VIII 82 (699/700), referring to an estate of the protosymboulos, i.e., the caliph, in the Arsinoite.

105 For changes under Mu'āwiya see R. G. Hoyland, 'New Documentary Evidence and the Early Islamic State', BSOAS 69 (2006) 395-416; C. Foss, 'Egypt under Mu'awiya. Part 1: Flavius Papas and Upper Egypt', BSOAS 72 (2009) 1-24; id., 'Egypt under Mu'awiya. Part 2: Middle Egypt, Fusțāṭ and Alexandria', BSOAS 72 (2009) 259-78.

106 See now J. Mabra, Princely Authority in the Early Marwānid State: The Life of 'Abd al-'Azizz b. Marwān (Piscataway, NJ, 2017). 
chartoularioi, Isaac and Athanasius. ${ }^{107}$ But there is good reason to hesitate over the picture presented in Severan texts. ${ }^{108}$ First of all, both the Life of Isaac and the HP hint at periods of broader conflict, besides those episodes in which 'Abd al-'Aziz threatens the patriarch for some misdemeanour. We have seen above that the HP describes how the governor detained Christian bishops at Hulwān for all of the period c. $697-$ c. $700 ;^{109}$ but it also then passes over a striking but obscure patriarchal interregnum between the death of the patriarch Simon (placed on 18.vii.700) and the consecration of Alexander (placed 25.iv.704). ${ }^{110}$ Both the HP and the Life, moreover, refer to an episode in which 'Abd al-'Aziz had ordered the smashing of crosses. The Life of Isaac places this at the beginning of his rule, and seems to associate it with his initial opposition to the patriarch John (as also reported in the $H P$ ); ${ }^{111}$ but the HP places it much later, before the death of Isaac (692), and adds the arresting detail that, 'He wrote a number of inscriptions and he placed them on the doors of the churches in Misr and the Delta, saying in them, "Muhammad is the great messenger of God, and Jesus also is the apostle of God. But God does not beget and is not begotten.",112 The reported inscription is reminiscent of those which adorned both the reformed coinage and 'Abd al-Malik's Dome of the Rock, and points to a new confidence in critiquing Christian dogma, and in proclaiming Islam as the religion of the new Arab empire. ${ }^{113}$

In contemporaneous documents, we also encounter several signs of tension between Christians and the regime of 'Abd al-'Azìz. Perhaps most significant is a text from the archive of Fl. Atias (Ar. Ațiyya) - pagarch of Arsinoe (c. 694-c. 697), and then dux of Arcadia and of the Thebaid (c. 697-c. 703). ${ }^{114}$ This Greek document, SB III 7240 (= P.BellTwoLetters 1), bears a bilingual protocol which recognises 'Abd al-'Azīz, and is dated to 20th Phaōphi of an 11th indiction, which must be 7.x.697.

107 See above fn. 67 and Booth (cf. fn. 45) for the effects of the Sixth Council.

108 Pace, e.g., M. Mikhail, From Byzantine to Islamic Egypt: Religion, Identity, and Politics after the Arab Conquest (London, 2014), e. g., 41; Mabra (cf. fn. 106) esp. 119-159.

109 Above fn. 92.

110 HP (Primitive) (Seybold 132-133); HP (Vulgate) (Evetts PO 5, 46-50)

111 Life of Isaac 11 (Porcher 347): 'Indeed when he had first come to Egypt, he attempted to do evil against the churches - he broke crosses and did much evil to the archbishop.'

112 HP (Primitive) (Seybold 122); HP (Vulgate) (Evetts PO 5, 25). Cf. also the various anti-Christian crimes attributed to 'Abd al-'Aziz's son al-Așbag, who was his father's subordinate; see HP (Vulgate) (Evetts PO 5, 50-51); HP (Primitive) (Seybold 133-134), and fn. 117 below.

113 For the Dome of the Rock inscriptions see, e.g., M. Milwright, The Dome of the Rock and Its Umayyad Mosaic Inscriptions (Edinburgh, 2016) (with 224-225 on the reported inscriptions in the HP). Cf. the Fusțāt inscription of 'Abd al-'Azīz cited from Maqrīzī in E. Combe et al., Répertoire chronologique d'épigraphie arabe (Cairo, 1931) 7-8 no. 8, dated 688/9 and devoid of distinctive religious language.

114 On the Atias archive see 189-197 in CPR VIII 72-84; to whose list add CPR XIX 17, SB XXIV 16219, SBKopt IV 1783, 1785, P.Gascou 28 and perhaps CPR IV 6. For the last text, which would extend Atias' dates from 699/700 to 703, see J. Cromwell, 'Coptic Texts in the Archive of Flavius Atias', ZPE 184 (2013) $280-288$. 
It is one of the earliest witnesses to the entrance of persons bearing Arabic names into the upper civil administration; but it also serves to correct our perspective on the fiscal situation of the monasteries under 'Abd al-'Azīz. Therein Fl. Atias addresses 'the inhabitants of "the Cup" on the mountain of Memnonia [Jeme],' and proclaims that he is writing to them, as to the other monasteries, concerning their poll-tax (diagraphon), which the monks had not paid 'at the time of the insurrection (en kairōi tēs antarsias).' Atias reissues a guarantee which the monks had obtained no doubt following the insurrection - from 'Ouoeith, [Ghuwayth?] former administrator of the Upper Country (i.e., dux of the Thebaid [and Arcadia?]),' and which allowed them to remain in return for the poll-tax. ${ }^{115}$ The date of the previous insurrection is uncertain, although it is possible that it should be placed in the rule of 'Abd al-'Azìz, and be seen as a direct response to the application of the poll-tax to individual ascetics. ${ }^{116}$ Whatever the case, it is often supposed - following the HP that the poll-tax was imposed on monasteries in c. $705 .{ }^{117}$ Our document demonstrates that it was applied to some monasteries, in Western Thebes if nowhere else, in the 690s.

We do not know when Mena's Life of Isaac was completed, except that it was within the author's lifetime and after his appointment c. $697-$ c. $700 ;{ }^{118}$ nor do we know the extent to which the relevant Lives within George's contribution to the HP (from John III to Alexander) are products of, and commentaries upon, the period of their compilation (c. 715). ${ }^{119}$ We must therefore be sensitive to the fact that the image of 'Abd al-'Azīz as the good ruler might be, at least in part, a construction from the perspective of his successors' rule, when the transformations witnessed in other sources for his governorship - the greater prominence of Islam and of Arabic in public culture; the apparent displacement of Christians within the higher and

115 For an edition and a discussion see H. I. Bell, 'Two Official Letters of the Arab Period', Journal of Egyptian Archaeology 12 (1926) 265-281, at 265-275.

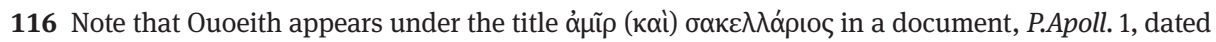
to a 2nd indiction. J. Gascou and K. Worp, 'Problèmes de documentation apollinopolite', ZPE 49 (1982) $83-95$, at $85-86$, read the title as indicating that Ouoeith was dux, placing the document in $688 / 9$ (earlier dates being excluded). Ouoeith also appears bearing the title sakellarios in a small fragment, SB 24 16316, dated $26 . i i$ ind. 14 (686?).

117 HP (Vulgate) (Evetts PO 5, 50-51); HP (Primitive) (Seybold 133-134) attributes the extension of the poll-tax over monks to al-Așbag b. 'Abd b. al-'Aziz, and suggests this occurred after the election of Alexander in 705. But al-Așbag died before his father, and one suspects that George is here attempting to deflect blame from 'Abd al-'Azīz.

118 See above fn. 78.

119 For this approach to George's contribution to the HP see C. Palombo, 'Constantinople and Alexandria between the Seventh and Eighth Centuries: The Representation of Byzantium in Christian Sources from Conquered Egypt', in N. S. Matheou et al. (eds), From Constantinople to the Frontier: The City and the Cities (Leiden, 2016) 243-259. 
lower levels of the provincial administration; and the extension of fiscal liabilities over monks - intensified and became more pervasive. ${ }^{120}$

The image of 'Abd al-'Azīz as the good Muslim ruler, like that of Heraclius as the bad Christian ruler, must therefore be appreciated against, and complicated through, wider evidence for his rule. But it is as crucial that both images be recognised as being in dialogue with the other. For Severan authors writing at the turn of the seventh and eighth centuries, the construction of Heraclius as persecutor - an inversion of his actual doctrinal instincts - served several purposes: to disguise the situation in the 630s, in which large numbers of Severans had entered into willing communion with Constantinople; to sanction the ongoing re-integration of 'lapsed' Severan communities, and of Chalcedonian monenergists; and to create a powerful shared narrative for the emergent Coptic Church. At the same time, their simultaneous image of 'Abd al-'Azìz served to minimise the actual tensions of his rule, when the processes of Islamisation and Arabisation were accelerating; to excuse the evident co-operation of the Severan leadership with the Arab-Muslim authorities; and to provide an idealised model for the future relationships of patriarch and governor. Each image progressed in tandem and in conversation, reinforcing the other and together witnessing a pivotal transition, in which Christian notions of good rulership were being transposed from the emperor at Constantinople to the emir at Fustāt.

120 For these changes see P. Sijpesteijn, Shaping a Muslim State: The World of a Mid-eighth Century Muslim Official (Oxford, 2013) esp. 91-216. 